\title{
ANALYSIS OF SELECTION OF ARSENAL WAREHOUSE LOCATIONS TO SUPPORT KRI OPERATIONS IN THE KOARMADA II AREA ANAL YSIS OF ARSENAL STORAGE LOCATION SELECTION TO SUPPORT THE OPERATIONS OF INDONESIAN NAVY WARSHIP (KRI) IN THE 2ND NAVAL FLEET TERRITORY
}

\author{
Muhammad Arif ${ }^{1}$, Budisantoso W. ${ }^{2}$, I Made Jiwa Astika ${ }^{3}$, Ayip Rivai ${ }^{4}$ \\ 1,3,4Indonesian Naval Technology College, Bumimoro-Morokrembangan, Surabaya 60187, Indonesia \\ 2Industrial Engineering Department, Institut Teknologi Sepuluh Nopember, Surabaya, Indonesia
}

\begin{abstract}
Uncertain global dynamics is one of the main factors influencing the successful achievement of goals and interests in the field of national defense. This reflects how important it is for stakeholders in the defense sector, to understand the dynamics of the strategic environment which presents a series of opportunities, obstacles to threats to the existence of the Republic of Indonesia, which in the end will obtain strategic steps to overcome them. The Indonesian Navy is strongly influenced by several components, such as the strength structure, the level of readiness, the level of sophistication or technological sophistication and the operational durability of its Alutsista. The synergy of the four components of strength is very much determined by the country's ability to build and maintain the ability of the defense equipment. Currently, Arsenal does not have a regional warehouse and there is only one central warehouse in Surabaya. The wide working area of Koarmada II, of course, requires a large number of KRI elements. Arsenal really need regional warehouses in order to be able to increase KRI's operational support in the Koarmada II working area. This is necessary considering that the operation at sea requires a very high presence of KRI. So that if there is a need for ammunition supplies, the process of supplying them can be carried out quickly. This research uses the Fuzzy Multi Criteria Decision Making (FMCDM) method. Overall, the results obtained from this study, it can be concluded that the best location from the alternative location is in the Koarmada II area, namely Lantamal Manado with the highest value of 0 .
\end{abstract}

Keywords: Determination of Location, Fuzzy Multi Criteria Decision Making (FMCDM).

\section{INTRODUCTION}

The Indonesian Navy is strongly influenced by several components, such as the strength structure, the level of readiness, the level of sophistication or technological sophistication and the operational durability of its Alutsista. The synergy of the four components of strength is very much determined by the country's ability to build and maintain the ability of the defense equipment. Ships of the Republic of Indonesia (KRI) as one of the components of the Integrated Fleet Weapon System (SSAT) are the foremost vital forces of Indonesia's defense to guard the maritime territory of the Unitary State of the Republic of Indonesia (NKRI). The direct correlation of the increase in defense equipment, of course, must be balanced between the level of need and support capacity so that it can directly improve operational capabilities in the field. Where the operational readiness of the unit can only be done optimally if it is supported by optimal logistics availability. One of them is through the logistical support role of weapons and ammunition from Arsenal (the Indonesian
Navy's arsenal of weapons and munitions) to meet the needs of KRI.

The direct role in supporting the needs of weapons and ammunition in the Indonesian Navy in storing, maintaining and distributing is under the Indonesian Navy (Dissenlekal) Weapons and Electronics Service Task Force (Dissenlekal), namely Arsenal. Some of Arsenal's functions according to KASAL Decree Number: Kep / 31 / VII / 1997 are compiling plans for the development of weapons materials including general weapons, special weapons, and ammunition including the facilities and infrastructure, compiling needs plans and proposing material procurement in order to help Disenlekal prepare plans the need for weapons and ammunition for the Indonesian Navy, carrying out reception and storage activities both in the context of filling regional warehouses and returning from user units.

This research was conducted because at this time Arsenal did not have a regional warehouse and there was only one central 
warehouse in Surabaya. The wide working area of Koarmada II, of course, requires a large number of KRI elements. Arsenal really need regional warehouses to be able to increase KRI's operational support in the Koarmada II working area. This is necessary considering the implementation of operations at sea requires a very high presence of KRI. So that if there is a need for supplies ammunition, the process of supplying it can be carried out quickly.

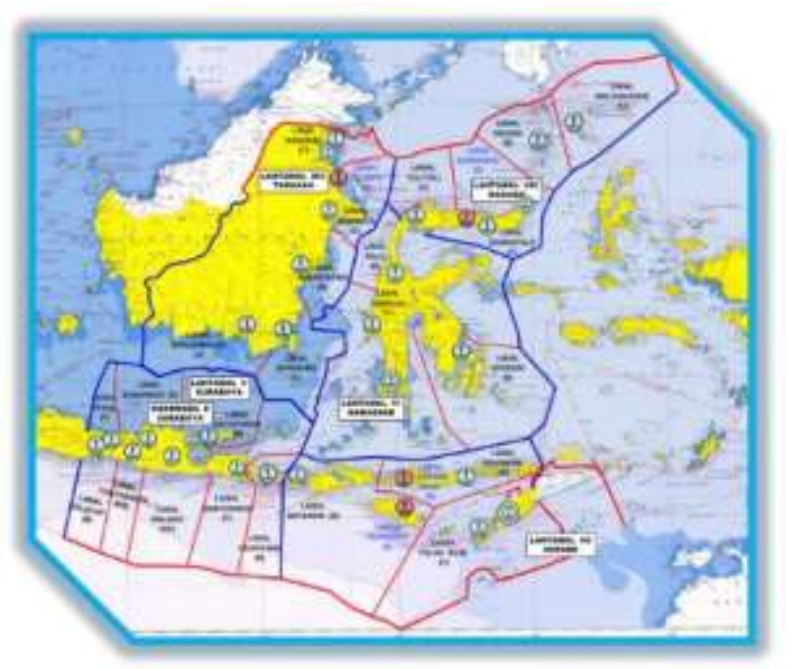

Figure 1. Koarmada II Working Area Source: Sops Koarmada II

\section{LITERATURE REVIEW}

\subsection{Previous Research}

In carrying out current research, there are several relevant studies in the form of theories in supporting problem solving. Regarding the gap in previous research, this research uses the fuzzy MCDM method. The reason the researchers chose this method is because the fuzzy MCDM method can solve the multicriteria problem in the process of determining the location of the Arsenal area warehouse and overcoming the possibility of data that is uncertain.

\subsection{Arsenal}

Arsenal is the Dissenlekal technical implementing element (UPT) in charge of carrying out material support for weapons, ammunition and special weapons to all elements / units of TNI users, Navy. (KEP Kasal Number KEP / 31 / VII / 1997, 1997). In its history, Arsenal was formed in 1927 by the Dutch as an ammunition depot, including docks, ammunition / mine workshops, and ammunition depots. Furthermore, during the Japanese occupation in 1942, improvements were carried out with the addition of the area and the addition of coastal defenses. In 1945, especially on 22 October TKR Laut controlled the ammunition depot.

\subsection{Fuzzy Theory}

\subsubsection{Definition of Fuzzy}

The concept of fuzzy theory was initiated by Lotfi A. Zadeh in 1965 with his seminary paper "Fuzzy Sets" (Zadeh, 1965). Prior to working with fuzzy theory, Zadeh used control theory. He developed the concept of "state", which is the basic form of modern control theory. Fuzzy theory shows that all theories can be used as the basic concept of fuzzy or continues membership function. Broadly speaking, fuzzy theory can be classified into five main areas, namely:

a. Fuzzy Mathematics, where the concept of classical mathematics is extended by changing classical sets with fuzzy sets;

b. Fuzzy Logic \& Artificial Intelligence, were approximations for classical logic

introduced and an expert system developed based on fuzzy information and thought forecasts;

c. Fuzzy System, which includes fuzzy control and fuzzy approaches to process and communication signals;

d. Uncertainty and Information, where differences from uncertainty are analysed; e. Fuzzy Decision Making, where consideration exists for optimization problems

\subsubsection{Fuzzy Membership}

The membership function is a curve that shows the mapping of data input points into their membership values (often referred to as membership degrees) which have an interval between 0 and 1 . One way that can be used to obtain membership values is through function approach. There are several functions that can be used.

a. Linear Representatiom

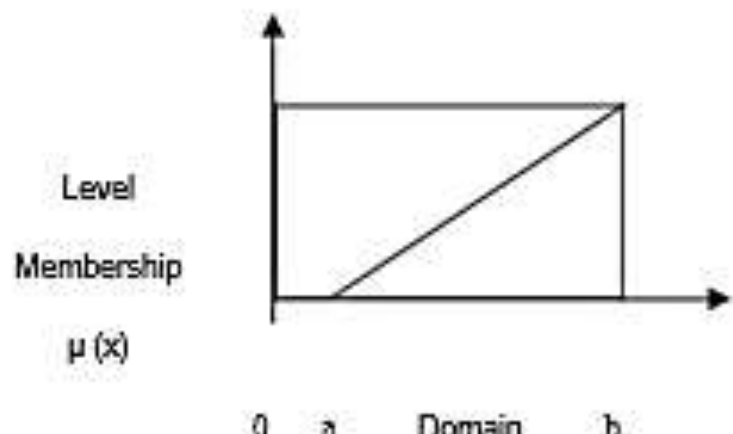

Figure 2. Linear Representation 


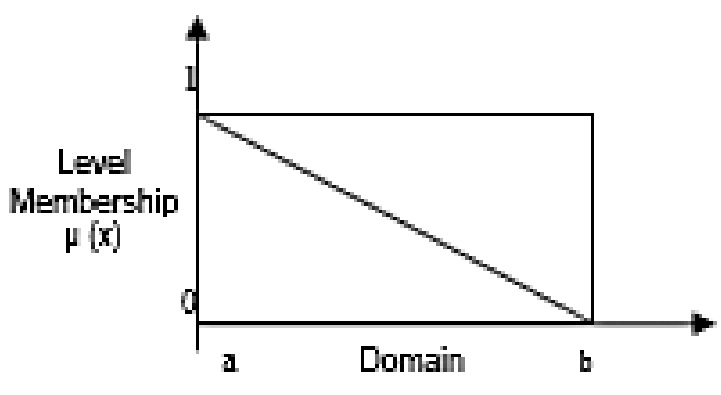

Figure 3. Derivative Linear Representation

b. Triangle Curve Representation

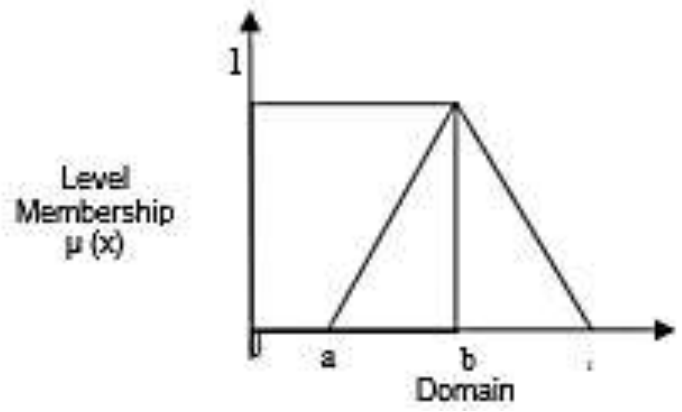

Figure 4. Triangle Curve

c. Trapezoid Curve Representation

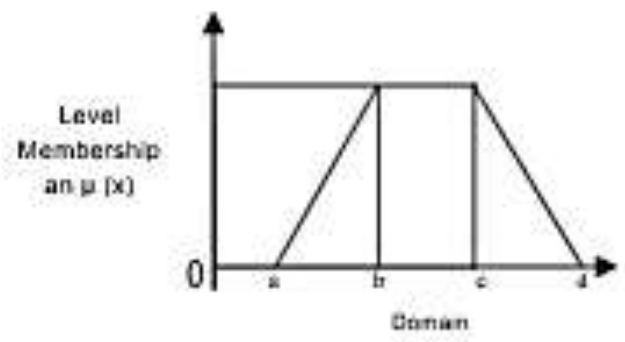

Figure 5. Trapezoid Curve

\subsubsection{Triangular Fuzzy Number (TFN)}

In TFN, each single (crisp) value has a membership function consisting of three values, each of which represents the lower value, the middle value and the upper value. Graphically the membership function with TFN can be illustrated as in the following figure:

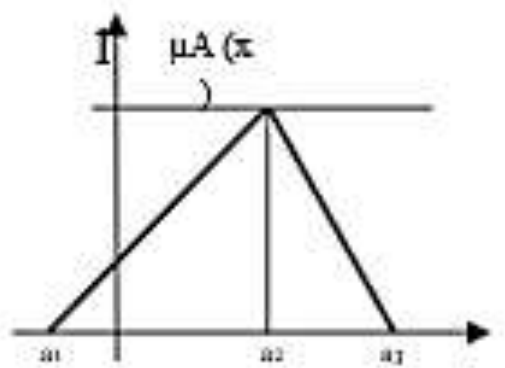

Figure 6. Triangular Fuzzy Number $A=\left(a_{1}, a_{2}, a_{3}\right)$

\subsubsection{Value Defuzzification}

Defuzzification is a process of converting and fuzzy quantity into a definite quantity, where the output and fuzzy process can be a logical combination of two or more fuzzy membership functions defined in accordance with the universe of discussion. Input and defuzzy process is a fuzzy set obtained from the composition of fuzzy rules, while the resulting output is a number in the domain of the fuzzy set. There are several defuzzification methods that are commonly used as follows:
a. Centroid Method (Center Of Gravity /
COG) Bisector Method
b.
c. Mean of Maximum (MOM) method
d. Largest of Maximum (LUM) method
e. Smallest of Maximun (SOM) Method

\subsubsection{Linguistic Variables}

A linguistic variable is a variable that has a description in the form of a fuzzy number and more generally a word that is represented by a fuzzy set. For example, descriptions of linguistic variables for temperature can be LOW, MEDIUM and HIGH where the descriptions are expressed as fuzzy values. (Tsoukalas, 1997). As with algebraic variables that use numbers as value while the linguistic variable uses words or sentences as its value which forms a set called a set of "terms", each value of the "term" is a fuzzy variable which defined based on base variable While the base variable defines the universe of speech for all fuzzy variables in the set of "terms" (Jantzen, 1998).

\subsubsection{Multiple Criteria Decision Making (MCDM)}

Multi-Criteria Decision Making (MCDM) is a decision-making method consisting of theories, processes, and analytical methods for decision making that involves uncertainty, dynamics, and multi-criteria aspects of the decision. Multi-Criteria Decision Making (MCDM) is the terminology used in solving problems where an MCDM approach is expected to get the best alternative.

\section{RESEARCH METHODOLOGY}

\subsection{Data Processing}

After obtaining data from the questionnaire, the next step is to recapitulate the results of the questionnaire and perform data processing. The data processing process uses the MCDM fuzzy algorithm (Liang \& Wang, 1994): 
a. Table weighting results of the qualitative criteria level assessment to obtain the aggregate weight value.

b. Table the results of the assessment rating or preference for each alternative based on existing qualitative criteria.

c. Determine the mean value of fuzzy numbers, by adding the values that appear at each level of the linguistic scale and then dividing the sum by the number of criteria whose values fall into the level of the linguistic assessment.

d. Determine the lower limit value and the upper limit value of a fuzzy number, where the lower limit value (ct $=b(i-1)$ ) is equal to the middle value of the level below it, while for the upper limit value $(b t=b(i-1))$ is the same as the midpoint of the level above.

e. Determining the aggregate weight of each qualitative criterion, because in this study a form of linguistic assessment is used that already has a triangular fuzzy number definition, the aggregation process is carried out by looking for the aggregate value of each lower limit value (c), the middle value $(\mathrm{a})$ and the upper limit value (b). f. Calculating the preference value of each alternative based on qualitative criteria. In calculating the aggregate weight of each alternative for each criterion.

g. Calculating the fuzzy index value from the results of the assessment of each alternative for the qualitative criteria denoted by $\mathrm{G}$.i. First, get the value of $M_{i t}$ and $N_{t}$, to get the fuzzy fit index value $\mathrm{G} . \mathrm{i}$ for each subjective criterion.

h. Calculate the utility value of each alternative for the qualitative criteria.

i. Calculating the ranking value of each alternative based on qualitative criteria.

j. Calculating the ranking value of each alternative based on quantitative criteria.

k. Calculate the total (final) ranking value of each alternative for the qualitative criteria and the quantitative criteria.

l. Choose the best alternative based on the highest ranking value.

\section{DATA PROCESSING AND ANALYSIS}

This research includes data processing Two steps in the method of determining the location using fuzzy MCDM. Previously, preliminary data was taken for perfection, namely through related agencies.

\subsection{Location Determination Data Collection}

\subsubsection{Alternative Arsenal warehouse locations}

a. Lantamal VI Makassar

The choice of the first alternative location, namely the TNI Navy VI Main Base in Makassar. The average tide of sea water occurs
2 times a day with varying heights of $0.2 \mathrm{~m}$ to 1.7 $\mathrm{m}$ and the average tidal process changes in time, a decline of 1 hour from the previous day.

\section{b. Lantamal VII Kupang}

The second alternative location is the main Indonesian Navy VII base in Kupang, East Nusa Tenggara. Lantamal VII Kupang oversees 4 naval bases, namely Lanal Pulau Rote, Lanal Maumere, Lanal Mataram and Yonmarhanlan VII Kupang.

\section{c. Lantamal VIII Manado}

The third alternative location is the main TNI AL III based in Bitung Manado. Lantamal VIII Manado.

\section{d. Lantamal XIII Tarakan}

Tarakan City is one of the cities in North Kalimantan Province, Indonesia and is also the 17 th richest city in Indonesia. This city has an area of $250.8 \mathrm{~km}^{2}$ and according to data from the Civil Registry and Family Planning Board, the City of Tarakan has a population of 239,787 people.

\subsubsection{Criteria Data in each Alternative}

a. Quantitative Criteria

1) Distance to field of operation.

The alternative distance to the field of operation is an important thing to pay attention to considering the $\mathrm{KRI}$ which will carry out the loading of ammunition from the operating area to the alternative warehouse in Arsenal short time in order to quickly return to the operating field.

Table 0.1 Alternative Distance Against Operation Area

\begin{tabular}{ccc}
\hline \multirow{2}{*}{ ALTERNATIVE } & \multicolumn{2}{c}{ SUB CRITERIA } \\
\cline { 2 - 3 } & DISTANCE & DISTANCE \\
& ALKI I & LCS \\
\hline Lantamal VI Makassar & $113 \mathrm{NM}$ & $634 \mathrm{NM}$ \\
Lantamal VII Kupang & $58 \mathrm{NM}$ & $1190 \mathrm{NM}$ \\
Lantamal VIII Manado & $30 \mathrm{NM}$ & $458 \mathrm{NM}$ \\
Lantamal XIII Tarakan & $55 \mathrm{NM}$ & $81 \mathrm{NM}$
\end{tabular}

2) Distance to city center.

Based on the standardization of the arsenal of weapons and ammunition in the Indonesian Navy, it is stated that for security from the impact of an explosion for some reason, the location of the ammunition warehouse for vital civilian and military objects is not less than 200m (Perkasal No. Perkasal / 100 / XII. / 2010, 2010). The following is the 
Alternative distance to the city center and the closest settlement:

Table 2. Alternative location distance to City Center and Settlements

\begin{tabular}{ccc}
\hline \multirow{2}{*}{ ALTERNATIVE } & \multicolumn{2}{c}{ SUB CRITERIA } \\
\cline { 2 - 3 } & DISTANCE & DISTANCE \\
& CITY CENTER & SETTLEMENT \\
\hline Lantamal VI Makassar & $3,6 \mathrm{KM}$ & $20 \mathrm{AD}$ \\
Lantamal VII Kupang & $17 \mathrm{KM}$ & $500 \mathrm{AD}$ \\
Lantamal VIII Manado & $37 \mathrm{KM}$ & $50 \mathrm{AD}$ \\
Lantamal XIII Tarakan & $9 \mathrm{KM}$ & $400 \mathrm{AD}$ \\
& & \\
\hline
\end{tabular}

3) Earthquake threat

Table 3. Score Acceleration Gravity Alternative Location

\begin{tabular}{ccc} 
No & $\begin{array}{c}\text { Alternative } \\
\text { Location }\end{array}$ & PGA \\
\hline 1. & Lantamal VI Makassar & 0.05 \\
2. & Lantamal VII Kupang & 0.40 \\
3. & Lantamal VIII Manado & 0.40 \\
4. & Lantamal XIII Tarakan & 0.05
\end{tabular}

b. Qualitative Criteria

In defining qualitative criteria determination of the location of Arsenal's warehouse, based on references to the Final Project of Major Dwi, Final Project of Marine Major I Komang and discussion of researchers with Arsenal expert staff on the basis of Perkasal No. 17.

\subsubsection{Data Processing}

Data processing using fuzzy MCDM, requires people who are experts in determining the scoring of the questionnaire that has beencompiled by researchers. These experts include:

a. Chief of arsenal as an expert in warehousing and weaponry at Arsenal Batuporon.

b. Asops Koarmada II as an expert in the field of KRI operations in the Fleet II Command area.

c. Asrena Koarmada II as an expert in planning in the Koarmada II Region

d. Commander of KRI Pari as a user in the field.

\section{CONCLUSIONS AND SUGGESTIONS}

\subsection{Conclusions}

After executing the whole process research, conclusions can be formulated based on the results of research methods and data processing and analysis, so the following conclusions can be drawn:

a. The criteria that are most influential in determining the criteria for the location of the warehouse for the arsenal are as follows:
1) Safe from enemies with a value of 9,124
2) Military Port with a value of
8,569
3) Transportation Facilities with a
value of 8,569

b. Based on data processing and analysis using the Fuzzy MCDM method, the best location results were obtained from alternative locations in the Koarmada II area, namely Manado Lantamal with the highest value of 0.284 then Lantamal Tarakan with a value of 0.260 , Lantamal Kupang with a value of 0.246 and Lantamal Makassar with a value of 0.210 .

\subsection{Suggestions}

Suggestions that can be continued for further researchers are:

a. In the stage of determining the criteria for determining the location of Arsenal's warehouse area, the researcher provides a future picture where at this time the researcher has not included the criteria for the social and cultural conditions of the surrounding community.

b. All the drawbacks in this study are due to the limitations of time and place as well as the difficulty of the research object which is a vital facility with a very classified classification constraints for researchers. However, this is become motivation and experience for researchers and information for researchers furthermore which will develop future research.

c. The results of this study are input for the organization, especially in determining the Arsenal warehouse area in the Koarmada II area

\section{ACKNOWLEDGEMENT}

The authors greatly acknowledge the support from Naval Technology College, STTAL Surabaya Indonesia for providing the necessary resources to carry out this research work. The authors are also grateful to the anonymous reviewers and journal editorial board for their many insightful comments, which have significantly improved this article. 


\section{REFERENCES}

Blanchard, BS, \& Fabrycky, WJ (2006) Systems engineering and analysis (4th ed.) New Jersey: Prentice Hall.

Franky. (2000). Warehousing Database. Bandung.

Hadiguna, RA, \& Setiawan, H. (2008). Layout Factory. Yogyakarta: ANDI.

Jantzen, J. (1998). Tutorial on Fuzzy Logic. Lyngby, Denmark: Department of Automation Technical University of Denmark.

June, D. (2014). Determination of Warehouse Location Arsenal supporters in Koarmatim with the Analytical Hierarchy Process (AHP) and Systematic Layout Planning (SLP) Methods. Surabaya: Naval College of Technology.

Krafcik, John F. (1988). "Triumph of the lean production system". Sloan Management Review. 30 (1): 41-52.

Kruse, Robert L. (1987) [1984]. Data Structures \& Program Design (second edition).

Law Number 34 (2004). Army Indonesian National. Jakarta, Indonesia.

Ministry of Public Works. (2017). Earthquake Hazard Map of Indonesia as Basic Reference Earthquake Resistant Infrastructure Planning and Design. Jakarta: Ministry of Public Works.

Ministry of Public Works. (2017). The 2010 Indonesia Earthquake Hazard Map as a basic reference for Earthquake Resistant Infrastructure Planning and Design. Jakarta: Ministry of Public Works.

Kep Kasal Number KEP / 31 / VII / 1997. (1997). Organization and Procedure of the Indonesian Navy's Electronic Weapons Material Service. Jakarta: Indonesian Navy.
Liang, \& Wang. (1999). A Hierarchy Fuzzy MCDM method for studying electronic marketing strategies in the information service industry. Journal of International Information Management, vol 8.

Pascal. (2016). China Allegedly Increased Defense Spending in the South China Sea. Jakarta: Compass.

TNI Commander Regulation Number 162 / XI / 2011. Technical Guidebook for Securing Armories and Ammunition in the TNI Environment with the theory of the location of August Losch.

Perkasal No. 17. (2008). Procedures for Storing Ammunition in the Indonesian Navy. Jakarta: Indonesian Navy.

Perkasal No. Perkasal / 100 / XII / 2010. (2010). Standardization of the Armory and Ammunition Building in the Indonesian Navy. Jakarta: Indonesian Navy.

Kasal Decree No. KEP / 1771 / XII / 2013 Dated23 December 2013 PUM 7.03. Standardization of Indonesian Navy Bases. Jakarta: Indonesian Navy.

Sritomo Wignjosoebroto. (2003). Factory Layout and Displacement Material. Surabaya: Gunawidya.

Tsoukalas. (1997). Fuzzy and Neural Approaches in Engineering. New York: John Willey and Son, Inc.

Zadeh, LA (1965). Fuzzy Set. Information and Control. 